\title{
Vaccination coverage rates of military personnel worldwide: a systematic review of the literature
}

\author{
Jana Nele Arnold ${ }^{1,2} \cdot$ Nils Gundlach $^{3} \cdot$ Irina Böckelmann ${ }^{2} \cdot$ Stefan Sammito ${ }^{2,4}([)$
}

Received: 5 December 2019 / Accepted: 10 June 2020 / Published online: 19 June 2020

(c) The Author(s) 2020

\begin{abstract}
Objectives Due to the professionally specific risk of infection in the armed forces, recommendations for vaccination are usually adapted for soldiers and are subject to special regulations. Little data is available on scientifically measured vaccination coverage of soldiers.

Methods A systematic literature research was carried out in the PubMed database using the search terms "army" or "military" or "Bundeswehr" and "vaccination" or "vaccine". Studies covering the period from 1990 to 2018 that contain statements on vaccination coverage rates of soldiers were identified. Twenty-two out of the initially found 1801 results were used.

Results The studies found were conducted in nine different countries with eight out of the 22 studies originating from the USA. The size of study was between 180 and 32,502 subjects. On average, the vaccination rates determined in the studies were between 26.8 and $94.7 \%$. Hepatitis A coverage was lowest (a minimum of $11.3 \%$ ) and tetanus vaccination coverage was highest (with a maximum of $94.7 \%$ ). Vaccination rates decreased with increasing age and coverage tended to be lower for men than for women. The term of service did not have a significant effect on vaccination rates.

Conclusions On the whole, most studies referred to recruits. They showed high vaccination rates for standard vaccinations and lower vaccination rates for indication and seasonal vaccinations. However, there were also vaccination gaps of temporary-career volunteers. This leads to a considerable effort at the armed forces to complete vaccine protection in case of a short-term operational commitment.
\end{abstract}

Keywords Bundeswehr $\cdot$ Prevention $\cdot$ Vaccine $\cdot$ Military personal

\section{Introduction}

Vaccinations are some of the most effective preventive measures with few side effects to prevent infectious diseases. The effectiveness of vaccinations for the population depends on high vaccination coverage. ${ }^{1}$ A vaccination rate of $75-94 \%$ is necessary to achieve a so-called herd immunity (Fine et al. 2011). This ensures that even people who cannot be vaccinated for medical reasons can receive the best

Stefan Sammito

stefansammito@bundeswehr.org

Bundeswehr Hospital Hamburg, Hamburg, Germany

2 Occupational Medicine, Otto-Von-Guericke University Magdeburg, Magdeburg, Germany

3 Medical Clinic Rotenburg, Rotenburg, Germany

4 Air Force Centre of Aerospace Medicine, Department I 3, Flughafenstraße 1, 51147 Cologne, Germany possible protection against diseases. Vaccination has drastically reduced the global number of cases of many infectious diseases. WHO data, for example, show a reduction in the documented pertussis cases from 1,982,355 in 1980 to 143,963 in 2017 . Only 96 cases of polio were reported in 2017, compared to 52,795 cases in 1980 (World Health Organization 2018). Furthermore, the WHO records the expected annual vaccination rates for different diseases. These data are officially submitted by the member states every year. The global vaccination rates are between $28 \%$ for rotavirus and $90 \%$ for the first tetanus vaccine (World Health Organization 2018). Data on the civilian population in Germany show a considerable lack of vaccine protection. The DEGS1-Study from 2013 reveals a vaccination from $71.4 \%(69.8-72.9 \%)$ against tetanus within the last 10 years and from $57.1 \%(53.3-58.9 \%)$ against diphtheria within the last 10 years (Poethko-Müller and Schmitz 2013). This lack of vaccine protection is repeatedly seen in outbreaks of

\footnotetext{
${ }_{1}$ Share of the vaccinated population in the total population.
} 
vaccine-preventable diseases such as the outbreak of measles in Cologne, Germany between January and August 2018 with 139 cases of measles (Osagie-Paech et al. 2019).

For soldiers $^{2}$ there are additional occupational risks of infection which can be prevented by vaccinations (Bundeswehr Medical Service Headquarter 2014; German Ministry of Defense 2014). It is plausible to assume that existing vaccination rates are generally above the rates of the general population due to the special employment of soldiers and the requirement of rapid deployability. However, there are also outbreaks of vaccine-preventable diseases among soldiers. From 2010 to 2011, there was a large outbreak of measles in the French military with the incidence increasing from $1: 100,000$ to $10.1: 100,000$ in 2010 and 41.4:100,000 in 2011 (Mayet et al. 2013). Furthermore, current results from the German armed forces (Bundeswehr) show that there are also vaccination deficiencies in this occupational group (Arnold et al. 2017). The following sections of this systematic review will examine the scope of vaccine requirements for soldiers of international armed forces according to published studies.

\section{Methods}

A systematic literature research was carried out to clarify the following two issues:

What are the vaccination rates of soldiers from other nations? The vaccinations of the so-called basic vaccine protection for Bundeswehr soldiers were used as examples for comparison because the vaccinations listed there are significant in the field of preventive medicine for a large part of the European continent and to facilitate the transferability to regular vaccinations for German soldiers.

Is there a difference between new employees (recruits) and temporary-career volunteers?

\section{Inclusion and exclusion criteria}

The systematic literature research in the PubMed database was carried out on 20 April 2018 using the search terms "army" or "military" or "Bundeswehr" and "vaccination" or "vaccine" or "Impfung". German and English articles published after 1 January 1990 were included. Consideration was given to cross-sectional studies dealing with vaccination rates of recruits or temporary-career volunteers. No distinction was made whether the vaccination rates were recorded using questionnaires or serological examination. All studies

\footnotetext{
${ }^{2}$ For better readability, only the masculine form is used in the following text, this always refers to female members of the armed forces.
}

that did not contain information on vaccinations of the basic vaccine protection of the Bundeswehr [tetanus, diphtheria, poliomyelitis, pertussis, hepatitis A, hepatitis B, measles, mumps, rubella (MMR) tick-borne encephalitis (TBE) and influenza] (Bundeswehr Medical Service Headquarter 2014) were excluded. In addition, the factors that were examined for a statistically significant influence on vaccination rates were documented.

\section{Systematic literature research}

The systematic search found 1,801 results for the abovementioned search terms (see Fig. 1). 431 of the articles found were published before 1990 and 157 articles were not available in English or German. After the titles and abstracts of the remaining 1213 results were screened, 35 results were suitable for the issue. Of these, eleven studies were excluded because they deviated from the issue (do not focus on vaccination rates of recruits or temporary-career volunteers or dealing with vaccines which do not belong to the basic vaccine protection for Bundeswehr soldiers). Two studies were excluded because there were no access rights to the full texts. Altogether 22 articles were taken into account in the systematic review.

\section{Results}

Of the 22 studies identified (see Table 1), eight studies come from the US Armed Forces (Clardy 1993; Eick et al. 2008; Kelley et al. 1991; Lewis 2015; Nevin and Niebuhr 2007; Scott et al. 2005; Smoak et al. 1994; Struewing et al. 1993), six studies from the Israel Defence Forces (Arav-Boger et al. 2000; Balicer et al. 2007; Huerta et al. 2006; Levine et al. 2011, 2012, 2015), two studies from the Norwegian Armed Forces (Flugsrud et al. 1997; Vainio et al. 2007) as well as one study from Brazil, Iran, Italy, Saudi Arabia, Spain and Thailand, respectively (Al-Khashan et al. 2011; Arteaga et al. 2010; Gonwong et al. 2016; Hosseini Shokouh et al. 2017; Passos et al. 2011; Rappuoli et al. 1993). With one exception, all studies considered are cross-section surveys of vaccination rates. In deviation from this, Eick et al. (2008) conducted a cohort study from 2000 to 2004 . The vaccination rates presented in this review originate from the basic data collection at the beginning of the study.

The number of subjects was between 180 in the study by Hosseini Shokouh et al. (2017) and 32,502 in the study by Lewis (2015).

15 studies recorded the vaccination rates via seroprevalence (Arav-Boger et al. 2000; Eick et al. 2008; Flugsrud et al. 1997; Gonwong et al. 2016; Hosseini Shokouh et al. 2017; Huerta et al. 2006; Levine et al. 2011, 2012, 2015; Lewis 2015; Nevin and Niebuhr 2007; Rappuoli et al. 1993; 


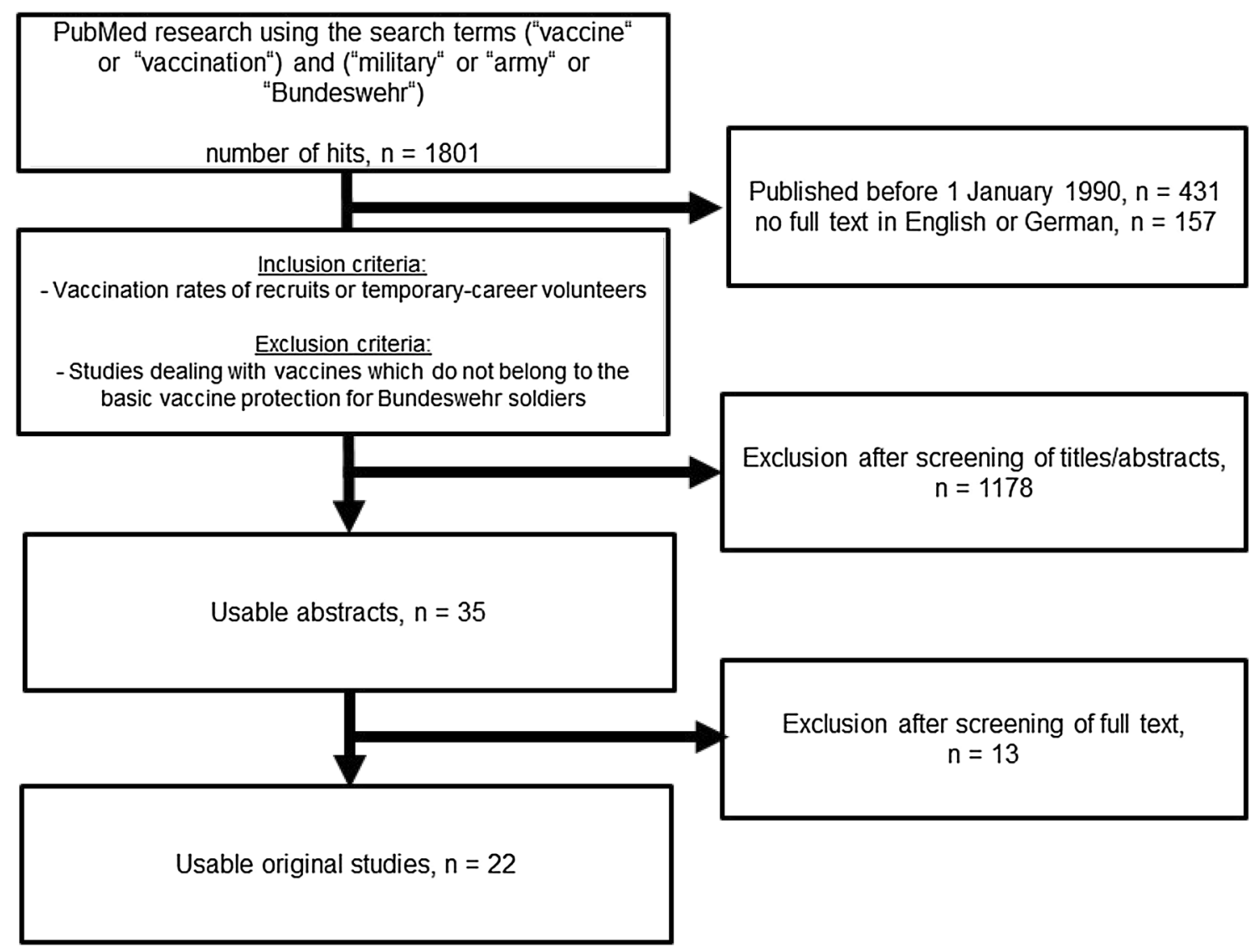

Fig. 1 Flowchart on study selection

Scott et al. 2005; Smoak et al. 1994; Vainio et al. 2007), three studies collected the data by means of questionnaires (Al-Khashan et al. 2011; Balicer et al. 2007; Struewing et al. 1993), and four studies combined the two procedures (Arteaga et al. 2010; Clardy 1993; Kelley et al. 1991; Passos et al. 2011) for determining the vaccination rates. The study by Arteaga et al. (2010) showed a positive predictive value of $98.8 \%$ for tetanus for the existence of seropositivity when stating a previous vaccination in the questionnaire.

The majority of the articles did not contain information on the armed services of the subjects, only seven studies provided information on this. The studies by Balicer et al. (2007), Clardy (1993), Lewis (2015) and Passos et al. (2011) examined Air Force members, the study by Smoak et al. (1994) Army soldiers and the study by Struewing et al. (1993) Navy/Marine Corps soldiers. The study by Scott et al. (2005) dealt with the armed service of each participant and conducted an additional sub-group analysis with regard to the vaccination status. This showed no significant differences in vaccination rates between the individual armed services.

Most studies were conducted with recruits. Only the three studies by Al-Khashan et al. (2011), Balicer et al. (2007) and
Hosseini Shokouh et al. (2017) examined soldiers who had been serving in the armed forces for quite some time. In this context, it must be stressed that the study by Al-Khashan et al. (2011) was the only one that considered the period of service at the time of study which was $14.9 \pm 7.8$ years.

The breakdown of study participants by age was carried out differently in the studies included. Inconsistent age intervals make the comparability of the studies more difficult. Altogether, only six studies described age groups over the age of 30 (Al-Khashan et al. 2011; Eick et al. 2008; Hosseini Shokouh et al. 2017; Kelley et al. 1991; Lewis 2015; Nevin and Niebuhr 2007). The examinations which captured averages showed values between 19.9 and 36.3 years (Arteaga et al. 2010; Balicer et al. 2007; Flugsrud et al. 1997; Smoak et al. 1994; Struewing et al. 1993). The study population mainly consisted of men with a percentage between 56 and $100 \%$.

The vaccination rates presented in the studies (see Table 2) were between $10.4 \%$ and $94.7 \%$. The vaccination rates for tetanus (94.0-94.7\%), diphtheria (77.0-77.4\%), poliomyelitis (85.4\%), mumps (80.3-91.6\%), measles (78.5-92.3\%) and rubella (81.6-94.8\%) were very high. The vaccination rates for pertussis $(58.6 \%)$ and hepatitis 
Table 1 Overview of the search results from the systematic literature research

\begin{tabular}{|c|c|c|c|c|c|c|c|c|}
\hline Study & Year & $\begin{array}{l}\text { Number of sub- } \\
\text { jects }\end{array}$ & Country/service & Time at military & $\begin{array}{l}\text { Type of data col- } \\
\text { lection }\end{array}$ & Age & $\widehat{\sigma}$ & 우 \\
\hline Al-Khashan et al. & 2011 & 2286 & $\begin{array}{l}\text { Saudi Arabia/all } \\
\text { armed services }\end{array}$ & $14.9 \pm 7.8$ years & Questionnaire & $36.3 \pm 7.5$ years & N/A & N/A \\
\hline Arav-Boger et al. & 2000 & 533 & Israel & Recruits & Seroprevalence & 17 or 18 years & $59.7 \%$ & $40.3 \%$ \\
\hline Arteaga et al. & 2010 & 226 & Spain & Recruits & $\begin{array}{c}\text { Seroprevalence, } \\
\text { Questionnaire }\end{array}$ & $20.2 \pm 1.7$ years & $92.5 \%$ & $7.5 \%$ \\
\hline Balicer et al. & 2007 & 942 & Israel/Air Force & N/A & Questionnaire & $22.5 \pm 5.1$ years & $80.2 \%$ & $19.8 \%$ \\
\hline Clardy F & 1993 & 276 & USA/Air Force & Recruits & $\begin{array}{l}\text { Seroprevalence, } \\
\text { Questionnaire }\end{array}$ & $\begin{array}{l}52.5 \%<20 \text { years, } \\
41.3 \% 20-24 \\
\text { years, } \\
6.2 \%>24 \text { years }\end{array}$ & $85.5 \%$ & $14.5 \%$ \\
\hline Eick et al. & 2008 & 3000 & USA/All Services & Recruits & $\begin{array}{l}\text { Cohort Study, } \\
\text { Seroprevalence }\end{array}$ & $\begin{array}{l}49.0 \% 17-19 \\
\text { years, } \\
39.9 \% 20-24 \\
\text { years, } \\
8.8 \% 25-29 \text { years, } \\
2.2 \% 30-35 \text { years }\end{array}$ & $79.0 \%$ & 21.0 \\
\hline Flugsrud et al. & 1997 & $\begin{array}{l}1188 \text { soldiers, } 695 \\
\text { civilians }\end{array}$ & Norway & Recruits & Seroprevalence & $\begin{array}{l}\text { Age } 18-28 \text { years, } \\
\text { Average } 20.7 \\
\text { years }\end{array}$ & $98.7 \%$ & 1.3 \\
\hline Gonwong et al. & 2016 & 7760 & Thailand & Recruits & Seroprevalence & $\begin{array}{l}15.2 \% 18-20 \\
\text { years, } \\
69.8 \% 21 \text { years, } \\
13.1 \% 22-24 \\
\text { years, } \\
1.9 \% 25-30 \text { years }\end{array}$ & $100 \%$ & $0 \%$ \\
\hline $\begin{array}{l}\text { Hosseini Shokouh } \\
\text { et al. }\end{array}$ & 2017 & $\begin{array}{l}180 \text { military staff, } \\
83 \text { civilians }\end{array}$ & Iran & N/A & Seroprevalence & $\begin{array}{l}27.2 \% 18-34 \\
\text { years, } \\
32.8 \% 35-50 \\
\text { years, } \\
40 \%>50 \text { years }\end{array}$ & $95.6 \%$ & $4.4 \%$ \\
\hline Huerta et al. & 2006 & 353 & Israel & Recruits & Seroprevalence & $95 \% 18-19$ years & $56.4 \%$ & $43.6 \%$ \\
\hline Kelley et al. & 1991 & 1547 & USA & Recruits & $\begin{array}{l}\text { Seroprevalence, } \\
\text { Questionnaire }\end{array}$ & $\begin{array}{l}\text { Alter } 17-35 \text { years, } \\
77 \%<20 \text { years }\end{array}$ & $73.7 \%$ & $26.3 \%$ \\
\hline Levine et al. & 2011 & 441 & Israel & Recruits & Seroprevalence & $95 \% 18-19$ years & $57.1 \%$ & $42.9 \%$ \\
\hline Levine et al. & 2012 & 416 & Israel & Recruits & Seroprevalence & $95 \% 18-19$ years & $57.5 \%$ & $42.5 \%$ \\
\hline Levine et al. & 2015 & 439 & Israel & Recruits & Seroprevalence & $95 \% 18-19$ years & $56.50 \%$ & $43.5 \%$ \\
\hline Lewis et al. & 2015 & 32,502 & USA/Air Force & Recruits & Seroprevalence & $\begin{array}{l}47.0 \% 17-19 \\
\text { years, } \\
42.9 \% 20-24 \\
\text { years, } \\
8.3 \% 25-29 \text { years, } \\
1.3 \% 30-35 \text { years, } \\
1.3 \%>35 \text { years }\end{array}$ & $78.6 \%$ & $21.4 \%$ \\
\hline Nevin and Niebuhr & 2007 & 2026 & USA & Recruits & Seroprevalence & $\begin{array}{l}14.1 \% 18-19 \\
\text { years, } \\
9.3 \% 20-24 \text { years, } \\
14.0 \% 25-29 \\
\text { years, } \\
11.8 \% 30-34 \\
\text { years }\end{array}$ & $82.6 \%$ & $17.4 \%$ \\
\hline Passos et al. & 2011 & 371 & Brazil/Air Force & Recruits & $\begin{array}{l}\text { Seroprevalence, } \\
\text { Questionnaire, } \\
\text { Vaccination card }\end{array}$ & 19-20 years & $100.0 \%$ & $0.0 \%$ \\
\hline Rappuoli et al. & 1993 & 334 & Italy & Recruits & Seroprevalence & $17-22$ years & N/A & N/A \\
\hline
\end{tabular}


Table 1 (continued)

\begin{tabular}{|c|c|c|c|c|c|c|c|c|}
\hline Study & Year & $\begin{array}{l}\text { Number of sub- } \\
\text { jects }\end{array}$ & Country/service & Time at military & $\begin{array}{l}\text { Type of data col- } \\
\text { lection }\end{array}$ & Age & $\hat{\sigma}$ & 우 \\
\hline Scott et al. & 2005 & 2400 & $\begin{array}{l}\text { USA / } \\
55 \% \text { army, } \\
26 \% \text { navy, } \\
19 \% \text { marine Corps }\end{array}$ & Recruits & Seroprevalence & $\begin{array}{ll}50 \% & 18-19 \text { years, } \\
25 \% & 20-23 \text { years, } \\
25 \% & 24-35 \text { years, }\end{array}$ & $81.5 \%$ & $18.5 \%$ \\
\hline Smoak et al. & 1994 & 1961 & USA/army & Recruits & Seroprevalence & $\begin{array}{l}\text { Average } 19.8 \\
\text { years }(1989)\end{array}$ & $59.0 \%$ & $41.0 \%$ \\
\hline Struewing et al. & 1993 & 1533 & $\begin{array}{l}\text { USA/navy, Marine } \\
\text { Corps }\end{array}$ & Recruits & Questionnaire & $\begin{array}{l}\text { Average } 20.3 \\
\text { years }(1990)\end{array}$ & $56.0 \%$ & $44.0 \%$ \\
\hline Vainio et al. & 2007 & 1405 & Norway & Recruits & Seroprevalence & $\begin{array}{l}74.1 \% 17-19 \\
\text { years, } \\
21.4 \% 20-24 \\
\text { years, } \\
3.7 \% \text { over } 25 \text { years }\end{array}$ & $90.8 \%$ & $9.2 \%$ \\
\hline
\end{tabular}

N/A not available/not applicable

Table 2 Vaccination rates for soldiers from different armed forces as a percentage and the resulting weighted averages for vaccinations which is the total of the vaccination rate multiplied by the quotient resulting from the number $\mathrm{n}$ and the number of all subjects where the vaccination rate for this disease was recorded

\begin{tabular}{|c|c|c|c|c|c|c|c|c|c|c|c|}
\hline Study & Number $\mathrm{n}$ & Tetanus & Diphtheria & Polio & Pertussis & HepA & НерВ & Mumps & Measles & Rubella & Influenza \\
\hline Al-Khashan et al. (2011) & 2286 & & & & & & & & & & $17.8 \%$ \\
\hline Arav-Boger et al. (2000) & 533 & & & & $58.6 \%$ & & & & & & \\
\hline Arteaga et al. (2010) & 226 & $94.2 \%$ & $77.4 \%$ & & & $10.4 \%$ & $78.3 \%$ & & & & \\
\hline Balicer et al. (2007) & 942 & & & & & & & & & & $48.5 \%$ \\
\hline Clardy (1993) & 276 & & & & & & & $83.0 \%$ & $80.4 \%$ & $85.5 \%$ & \\
\hline Eick et al. (2008) & 3000 & & & & & & & $91.6 \%$ & $86.1 \%$ & $94.8 \%$ & \\
\hline Flugsrud et al. (1997) & 1188 & & & & & & & & $92.3 \%$ & & \\
\hline Gonwong et al. (2016) & 7760 & & & & & & & & $78.5 \%$ & & \\
\hline Hosseini Shokouh et al. (2017) & 180 & $94.0 \%$ & $77.0 \%$ & & & & & & & & \\
\hline Huerta et al. (2006) & 353 & & & & & & & $83.3 \%$ & & & \\
\hline Kelley et al. (1991) & 1547 & & & $85.4 \%$ & & & & $84.4 \%$ & $79.3 \%$ & $82.5 \%$ & \\
\hline Levine et al. (2011) & 441 & & & & & & & $83.7 \%$ & & & \\
\hline Levine et al. (2012) & 416 & & & & & & & & & $87.7 \%$ & \\
\hline Levine et al. (2015) & 439 & & & & & & & & $85.7 \%$ & & \\
\hline Lewis et al. (2015) & 32,502 & & & & & & & $80.3 \%$ & $81.6 \%$ & $82.1 \%$ & \\
\hline Nevin and Niebuhr (2007) & 2026 & & & & & $12.0 \%$ & & & & & \\
\hline Passos et al. (2011) & 371 & & & & & & $84.0 \%$ & & & & \\
\hline Rappuoli et al. (1993) & 334 & $94.7 \%$ & $77.1 \%$ & & & & & & & & \\
\hline Scott et al. (2005) & 2400 & & & & & & $31.5 \%$ & & & & \\
\hline \multirow[t]{2}{*}{ Smoak et al. (1994) } & 969 (1989) & & & & & & & $83.8 \%$ & $78.7 \%$ & $81.6 \%$ & \\
\hline & 992 (1990) & & & & & & & $85.3 \%$ & $87.5 \%$ & $85.7 \%$ & \\
\hline Struewing et al. (1993) & 1533 & & & & & & & $87.7 \%$ & $82.2 \%$ & & \\
\hline Vainio et al. (2007) & 1405 & & & & & & & & $89.3 \%$ & & \\
\hline Weighted average & & $94.4 \%$ & $77.2 \%$ & $85.4 \%$ & $58.6 \%$ & $11.9 \%$ & $41.5 \%$ & $81.8 \%$ & $81.9 \%$ & $83.2 \%$ & $26.8 \%$ \\
\hline
\end{tabular}

B (31.5-84.0\%) were in the mid-range. With $78.3 \%$ or $84.0 \%$, the rates for hepatitis B were significantly higher in the studies by Arteaga et al. (2010) and Passos et al. (2011) than those in the study by Scott et al. (2005) with
$31.5 \%$. In contrast, the vaccination rates for influenza (17.8-48.5\%) and hepatitis A (10.4-12.0\%) were low. The weighted averages were then calculated in relation to the 
relevant number of subjects $n$. These were between $11.9 \%$ for hepatitis A and $94.4 \%$ for tetanus.

In the studies examined, several reasons were given for the lack of vaccination. In the study by Al-Khashan et al. (2011) 50.3\% of the interviewed persons did not know whether there was current vaccine protection against influenza. In the study by Balicer et al. (2007) $10.8 \%$ of the subjects who had refused vaccination were asked for their reasons. $37.7 \%$ were afraid of adverse effects of vaccination, $32.1 \%$ did not believe in the effectiveness of vaccination, $23.1 \%$ rejected vaccination generally and $5.1 \%$ stated other reasons.

Most studies examined statistically significant deviations of vaccination rates taking into account different influencing factors (Table 3). The variables differed considerably from study to study; age and gender of the subjects were most frequently and most consistently analyzed.

With regard to age, seven studies revealed a significantly $(p<0.05)$ lower seropositivity (Balicer et al. 2007; Eick et al. 2008; Gonwong et al. 2016; Hosseini Shokouh et al. 2017; Scott et al. 2005; Smoak et al. 1994; Struewing et al. 1993) in older age groups. The study by Clardy (1993) showed a higher seropositivity among older age groups and the study by Lewis (2015) returned contradictory results for mumps, rubella and measles. Four other studies revealed no significant effect of age (Al-Khashan et al. 2011; Arteaga et al. 2010; Flugsrud et al. 1997; Levine et al. 2011).

In eight studies, gender proved to be a significant influencing factor. In seven studies, seropositivity was higher in women than in men (Arav-Boger et al. 2000; Clardy 1993; Kelley et al. 1991; Levine et al. 2012; Lewis 2015; Scott et al. 2005; Smoak et al. 1994). Only in the study by Hosseini Shokouh et al. (2017) men were better immunized against diphtheria than women. Nine studies showed no statistically significant effect of gender (Arteaga et al. 2010; Balicer et al. 2007; Eick et al. 2008; Hosseini Shokouh et al. 2017; Huerta et al. 2006; Levine et al. 2011, 2015; Nevin and Niebuhr 2007; Vainio et al. 2007).

Other variables in the different studies were, for example, rank, armed service, education, income, country/region of origin, skin color or ethnic background. These could not be considered in the analysis due to their inconsistency.

\section{Discussion}

This systematic review provides the first overview of scientific studies which dealt with the vaccination rates of activeduty military personnel. On the whole, the studies show that there is still a need for improvement in the armed forces with regard to the completion of vaccination rates of soldiers, particularly since they are exposed to significant risks due to their professional activities.
Information on the current vaccination recommendations from the different countries were only available for the civilian population. There was no access to the military provisions because, like the recommendations of the Bundeswehr, they are published in non-accessible guidelines and are partially treated as classified information.

Most studies which could be identified in the context of this systematic literature research examined vaccination rates of recruits. This probably results from the fact that recruits are a cohort which can be easily analyzed in the context of their pre-employment medical examination. There is little data available on temporary-career volunteers.

In the studies found, both information from the soldiers and serological results were used to determine the vaccine protection of the subjects. A low serological titer does not necessarily mean that no vaccination has been carried out but several studies show a high degree of conformity between anamnestic information and serology with positive predictive values over 90\% (Alp et al. 2012; Ferson et al. 1994). For this reason, both methods were equally used in this review.

Altogether, most variable results were obtained with regard to vaccination rates of soldiers. Vaccination coverage rates for the well-established vaccines of tetanus, diphtheria, poliomyelitis, mumps, measles and rubella were mostly very high. In this case, herd immunity can be assumed. Apart from the long time availability of the vaccine, this could be because these vaccines are administered systematically from early childhood and thus high seropositivity can be assumed in young adults. Furthermore, these are vaccinations that show long phases of vaccine protection after basic immunization has been completed.

Particularly noticeable were the low vaccination rates for hepatitis A and influenza. This can be explained by the fact that influenza is a seasonal vaccine which needs to be refreshed annually (Impfkommission 2017). Hepatitis A, however, is a vaccine which is not one of the standard vaccines in childhood in the surveyed countries (Spain and USA) (Centers for Disease Control and Prevention 2018; Moreno-Pérez et al. 2017). Therefore, a high vaccination status could not be expected for the examined recruits.

The lack of knowledge of many soldiers of their own vaccination status also indicates that many soldiers are not sufficiently informed of the preventive effect of vaccination or consider this potential protective effect to be of minor importance. The reasons for a negative stance towards vaccination stated in the study by Balicer et al. (2007) could also be due to a lack of information on vaccination.

In summary, all examined soldiers showed large vaccination gaps so that great effort is needed in the relevant armies to establish full protection. This reduces the basic operational readiness of the armed forces and threatens the health 
Table 3 Breakdown of the potential influencing factors age and gender into significant or insignificant effects on seropositivity

\begin{tabular}{|c|c|c|}
\hline Study & Significant variables & Insignificant variables \\
\hline Al-Khashan et al. (2011) & & Age $(p=0.849)$ \\
\hline Arav-Boger et al. (2000) & Women $>$ men $(p=0.002)$ & \\
\hline Arteaga et al. (2010) & & Age, gender \\
\hline Balicer et al. (2007) & Age $($ age $\uparrow \rightarrow$ seropositivity $\downarrow)(p=0.001)$ & Gender $(p=0.872)$ \\
\hline Clardy (1993) & Age (age $\uparrow \rightarrow$ seropositivity $\uparrow$ ), women $>$ men & \\
\hline Eick et al. (2008) & Age (age $\uparrow \rightarrow$ seropositivity $\downarrow)(p \leq 0.05)$ & Gender \\
\hline Flugsrud et al. (1997) & & Age $(p>0.05)$ \\
\hline Gonwong et al. (2016) & Age $($ age $\uparrow \rightarrow$ seropositivity $\downarrow)(p<0.05)$ & \\
\hline Hosseini Shokouh et al. (2017) & $\begin{array}{l}\text { Age (age } \uparrow \rightarrow \text { seropositivity } \downarrow) \text { for tetanus }(p<0.01) \text {, for diphtheria } \\
\quad(p=0.047) \text {, for diphtheria men }>\text { women }(p=0.049)\end{array}$ & Gender in case of tetanus \\
\hline Huerta et al. (2006) & & Gender $(p=0.13)$ \\
\hline Kelley et al. (1991) & Age (age $\uparrow \rightarrow$ seropositivity $\downarrow)(p=0.005)$, Women $>$ Men & \\
\hline Levine et al. (2011) & & Gender $(p=0.31)$, age $(p=0.18)$ \\
\hline Levine et al. (2012) & Women $>$ men $(p<0.01)$ & \\
\hline Levine et al. (2015) & & Gender \\
\hline Lewis et al. (2015) & $\begin{array}{l}\text { Measles (age } \uparrow \rightarrow \text { seropositivity } \downarrow)(p<0.001) \text {, Mumps and Rubella (age } \\
\uparrow \rightarrow \text { seropositivity } \uparrow)(p=0.002) \text {, women }>\text { men }(p<0.001)\end{array}$ & \\
\hline Nevin and Niebuhr (2007) & Age $(p=0.015)$ & Gender \\
\hline Passos et al. (2011) & Age $(p=0.035)$ & \\
\hline \multicolumn{3}{|l|}{ Rappuoli et al. (1993) } \\
\hline Scott et al. (2005) & Age $($ age $\uparrow \rightarrow$ seropositivity $\downarrow)(p>0.01)$, women $>$ men $(p>0.01)$ & \\
\hline Smoak et al. (1994) & Age (age $\uparrow \rightarrow$ seropositivity $\downarrow$ ), women $>$ men & \\
\hline Struewing et al. (1993) & Measles/Mumps in women (age $\uparrow \rightarrow$ seropositivity $\downarrow)(p<0.05)$ & Measles/Mumps in men \\
\hline Vainio et al. (2007) & & Gender \\
\hline
\end{tabular}

If available in the studies, the relevant probability coefficient $(p)$ is given

of the individual soldiers in case of short-notice operations, especially disaster relief.

Acknowledgements Open Access funding provided by Projekt DEAL.

Funding This research did not receive any specific grant from funding agencies in the public, commercial, or not-for-profit sectors.

\section{Compliance with ethical standards}

Conflict of interest The authors declare that they have no conflict of interest.

Open Access This article is licensed under a Creative Commons Attribution 4.0 International License, which permits use, sharing, adaptation, distribution and reproduction in any medium or format, as long as you give appropriate credit to the original author(s) and the source, provide a link to the Creative Commons licence, and indicate if changes were made. The images or other third party material in this article are included in the article's Creative Commons licence, unless indicated otherwise in a credit line to the material. If material is not included in the article's Creative Commons licence and your intended use is not permitted by statutory regulation or exceeds the permitted use, you will need to obtain permission directly from the copyright holder. To view a copy of this licence, visit http://creativecommons.org/licenses/by/4.0/.

\section{References}

Al-Khashan HI, Selim MA, Mishriky AM, Binsaeed AA (2011) Meningitis and seasonal influenza vaccination coverage among military personnel in central Saudi Arabia. Saudi Med J 32(2):159-165

Alp E, Cevahir F, Gökahmetoglu S, Demiraslan H, Doganay M (2012) Prevaccination screening of health-care workers for immunity to measles, rubella, mumps, and varicella in a developing country: what do we save? J Infect Public Health 5(2):127-132

Arav-Boger R, Ashkenazi S, Gdalevich M, Cohen D, Danon YL (2000) Seroprevalence of pertussis antibodies among adolescents in Israel. Israel Med Assoc J 2(2):174-177

Arnold JN, Gundlach N, Böckelmann I, Sammito S (2017) Randomisierte kontrollierte Kohortenstudie zur Quantitätssteigerung von Impfraten beim Basisimpfschutz von Soldaten der Bundeswehr. Wehrmed Mschr 61(12):302-304

Arteaga A, Desviat PV, Jaqueti J, Santos J, de Miguel AG, Garcia RJ (2010) Self-reported history of vaccination and disease and immunity against hepatitis A, hepatitis B, tetanus, diphtheria and varicella among Spanish military recruits. Human Vaccines 6(2):198-201

Balicer RD, Grotto I, Huerta M, Levian Y, Davidovitch N (2007) Influenza vaccine refusal in Israeli young adults. Mil Med 172(10):1093-1095

Bundeswehr Medical Service Headquarter (2014) Zentralvorschrift A1-840/8-4000: Impf- und weitere ausgewählte Prophylaxemaßnahmen für die Bundeswehr Fachlicher Teil. 
Centers for Disease Control and Prevention (2018) Recommended immunizations for infants and children (birth through 6 years): 2018

Clardy WF (1993) Susceptibility in USAF recruits to vaccine-preventable diseases. Vaccine 11(5):573-575

Eick AA, Hu Z, Wang Z, Nevin RL (2008) Incidence of mumps and immunity to measles, mumps and rubella among US military recruits, 2000-2004. Vaccine 26(4):494-501

Ferson MJ, Robertson PW, Whybin LR (1994) Cost effectiveness of prevaccination screening of health care workers for immunity to measles, rubella and mumps. Med J Aust 160(8):478-482

Fine P, Eames K, Heymann DL (2011) "Herd immunity": a rough guide. Clin Infect Dis 52(7):911-916

Flugsrud LB, Rłd TO, Aasen S, Berdal BP (1997) Measles antibodies and herd immunity in 20- and 40-year-old Norwegians. Scand J Infect Dis 29(2): 137-140

German Ministry of Defense (2014) Zentrale Dienstvorschrift A-840/8: Impf- und weitere ausgewählte Prophylaxemaßnahmen—organisatorischer Teil.

Gonwong S, Chuenchitra T, Khantapura P, Islam D, Mason CJ (2016) Measles susceptibility in young Thai men suggests need for young adult measles vaccination: a cross sectional study. BMC Public Health 16:309

Hosseini Shokouh SJ, Mohammadi B, Rajabi J, Mohammadian Roshan G (2017) Immunity to diphtheria and tetanus in army personnel and adult civilians in Mashhad. Iran Jpn J Infect Dis 70(2):132-135

Huerta M, Davidovitch N, Aboudy Y, Ankol OE, Balicer RD, Zarka S, Grotto I (2006) Declining population immunity to mumps among Israeli military recruits. Vaccine 24(37-39):6300-6303

Impfkommission (2017) Empfehlungen der Ständigen Impfkommission (STIKO) am Robert Koch-Institut 2017. Epid Bull 34:333-380

Kelley PW, Petruccelli BP, Stehr-Green P, Erickson RL, Mason CJ (1991) The susceptibility of young adult Americans to vaccinepreventable infections. A national serosurvey of US Army recruits. JAMA 266(19):2724-2729

Levine H, Ankol OE, Rozhavski V, Davidovitch N, Aboudy Y, Zarka S, Balicer RD (2011) Sub-optimal prevalence of mumps antibodies in a population based study of young adults in Israel after 20 years of two dose universal vaccination policy. Vaccine 29(15):2785-2790

Levine H, Ankol OE, Rozhavski V, Davidovitch N, Aboudy Y, Zarka S, Balicer RD (2012) Rubella seroprevalence in the first birth cohort reaching fertility age after 20 years of two dose universal vaccination policy in Israel. Vaccine 30(50):7260-7264

Levine H, Zarka S, Ankol OE, Rozhavski V, Davidovitch N, Aboudy Y, Balicer RD (2015) Seroprevalence of measles, mumps and rubella among young adults, after 20 years of universal 2-dose MMR vaccination in Israel. Human Vaccines Immunother 11(6):1400-1405

Lewis PE (2015) Surveillance snapshot: prevalence of antibodies to viral causes of vaccine-preventable illnesses by state home of record among Air Force recruits, 25 April 2013-24 April 2014. MSMR 22(7):18-19

Mayet A, Genicon C, Duron S, Haus-Cheymol R, Ficko C, Bédubourg G, Laporal S, Trichereau J, Meynard J-B, Deparis X, Migliani R (2013) The measles outbreak in the French military forces-2010-2011: results of epidemiological surveillance. J Infect 66(3):271-277

Moreno-Pérez D, Álvarez García FJ, Arístegui Fernández J, Cilleruelo Ortega MJ, Corretger Rauet JM, García Sánchez N, Hernández Merino Á, Hernández-Sampelayo Matos T, Merino Moína M, Ortigosa Del Castillo L, Ruiz-Contreras J (2017) Calendario de vacunaciones de la Asociación Española de Pediatría (CAV-AEP): recomendaciones 2017 (Immunisation schedule of the Spanish Association of Paediatrics: 2017 recommendations). Anales de pediatria (Barcelona, Spain: 2013) 86(2):98.e1-98.e9

Nevin RL, Niebuhr DW (2007) Rising hepatitis A immunity in U.S. military recruits. Military Med 172(7):787-793

Osagie-Paech IR, Bunte A, Ademi K, Gallo S, Hurraß J, Kelzenberg N, Lüttgen J, Stöhr G, Thienelt F, Winkelhog T, Winkler M, Wiesmüller GA (2019) Erkenntnisse aus dem Masernausbruch 2018 in Köln. In: 69. Wissenschaftlicher Kongress des Bundesverbandes der Ärztinnen und Ärzte des Öffentlichen Gesundheitsdienstes (BVÖGD) und des Bundesverbandes der Zahnärzte des Öffentlichen Gesundheitsdienstes (BZÖG) in Zusammenarbeit mit der Gesellschaft Hygiene, Umweltmedizin und Präventivmedizin (GHUP). Georg Thieme Verlag KG, New York

Passos AM, Treitinger A, Spada C (2011) Hepatitis B immunity and vaccination coverage among young adult males in the Air Force in South Brazil. Vaccine 29(49):9284-9288

Poethko-Müller C, Schmitz R (2013) Impfstatus von Erwachsenen in Deutschland: Ergebnisse der Studie zur Gesundheit Erwachsener in Deutschland (DEGS1) (Vaccination coverage in German adults: results of the German Health Interview and Examination Survey for Adults (DEGS1)). Bundesgesundheitsblatt, Gesundheitsforschung, Gesundheitsschutz 56(5-6):845-857

Rappuoli R, Podda A, Giovannoni F, Nencioni L, Peragallo M, Francolini $P$ (1993) Absence of protective immunity against diphtheria in a large proportion of young adults. Vaccine 11(5):576-577

Scott PT, Niebuhr DW, McGready JB, Gaydos JC (2005) Hepatitis B immunity in United States military recruits. J Infect Dis 191(11):1835-1841

Smoak BL, Novakoski WL, Mason CJ, Erickson RL (1994) Evidence for a recent decrease in measles susceptibility among young American adults. J Infect Dis 170(1):216-219

Struewing JP, Hyams KC, Tueller JE, Gray GC (1993) The risk of measles, mumps, and varicella among young adults: a serosurvey of US Navy and Marine Corps recruits. Am J Public Health 83(12):1717-1720

Vainio K, Samdal HH, Anestad G, Skutlaberg DH, Bransdal KT, Mundal R, Aaberge I (2007) Seroprevalence of measles among Norwegian military conscripts in 2004. Eur J Clin Microbiol Infect Dis 26(3):217-220

World Health Organization (2018) Global and regional immunization profile. World Health Organization, Geneva

Publisher's Note Springer Nature remains neutral with regard to jurisdictional claims in published maps and institutional affiliations. 